\title{
ПРОБЛЕМА ФОРМИРОВАНИЯ МОТИВАЦИИ ДОСТИЖЕНИЙ СТУДЕНТОВ ГУМАНИТАРНЫХ ВУЗОВ
}

\author{
А.С. Милентьева \\ Московский гуманитарный университет
}

\begin{abstract}
Аннотация: В статье автор раскрывает важность взаимосвязи иееностных ориентаций и мотивации достижений студентов для формирования личности, оптимизачии работы студентов, раскрытия их потенциальных возможностей. Автор обосновывает использование термина «механизм волевого действия», воспитание которого сможет компенсировать недостаточную мотивачию обучающихся.
\end{abstract}

Ключевые слова: иенностные ориентации, мотивация, личность, волевое действие

\section{THE PROBLEM OF FORMATION OF ACHIEVEMENT MOTIVATION AMONG STUDENTS OF HUMANITIES UNIVERSITIES}

\author{
A.S. Milentyeva \\ Moscow University for the Humanities
}

\begin{abstract}
The author reveals the importance of the relationship between value orientations and motivation of students 'achievements for the formation of students' personality, optimization of students'work, and disclosure of their potential opportunities in the article. The author justifies using of the term «mechanism of volitional action», the education of which can compensate for the lack of motivation of students.
\end{abstract}

Keywords: value orientations, motivation, personality, volitional action

Формирование ценностных ориентаций и мотивации студентов является крайне важным направлением развития личности обучающихся ВУЗов. В процессе развития общества и условий жизни появляются все новые ценностные ориентации и мотивации молодежи, которые являются отражением образа жизни обучающихся, задают цели, к реализации которых мы стремимся. Вследствие чего меняются и качества личности современных студентов. Наряду с ценностными ориентациями значимое место в структуре личности занимает мотивация человека.

Мотивация - это готовность индивида к определенной деятельности, а также - умение прикладывать усилия ради достижения поставленных им целей под влиянием внешних и внутренних факторов. Главная суть мотивации заключается в удовлетворении индивидуальных потребностей человека.

В настоящее время исследование ценностных ориентаций является наиболее актуальным в связи с тем, что ценности, которые возникают в современном обществе - это показатель уровня культуры и отражение общественного поведения. Ценностные ориентации индивида рождают его цели и являются основой выбора жизненного пути, а меняющиеся условия жизни оказывают прямое влияние на возникающие в процессе ценности. 
Если рассматривать ценности на индивидуальном уровне, то они выступают как основы мотивов, двигающих людьми в процессе принятия важных решений в обыденной жизни. Мотив - это осознанное побуждение удовлетворить свои потребности, т.е. это толчок и причина, по которой человек начинает что-то делать для достижения поставленной цели.

\section{Ценностные ориентации и типы личности}

В 1914 г. появилась работа Э. Шпрангера «Формы жизни», в которой он выделил шесть типов личности в зависимости от их ценностных ориентации (Шпрангер, 2014), а затем Оллпорт, опираясь на модель Шпрангера, разработал подобную классификацию, представленную как черты ценностей (Оллпорт, 2015).

Назовем основные характеристики типов личности.

I. Теоретическая - личность, направленная на поиск истины, познание, она рациональна, руководствуется эмпирическими методами. Такой тип личности - высокоинтеллектуален, зачастую занят в области фундаментальной науки или философии.

II. Экономическая - личность, которая ищет для себя выгоду и пользу. Такие люди крайне практичные, заинтересованы в увеличении прибыли, зарабатывании денег, предпочитают получать только «полезные» знания, которые смогут применить для достижения цели или иной выгоды. Большинство известных бизнесменов, техников и технологов являются личностями данного склада.

III. Эстетическая - такая личность в первую очередь заинтересована в красоте и гармонии. Такие люди воспринимают жизнь, как наслаждение и действуют ради себя и своего блага. Они не всегда проявляют творческие способности, но склонны интересоваться эстетическими сторонами жизни.

IV. Социальная - ценностью такого типа личности является любовь к людям. Такие люди считают любовь единственным уместным и гуманным подходом к жизни. Такие люди альтруистичны, религиозные ценности для этого типа личности особенно важны.

V. Политическая - для политического типа личности особенно важна власть. К данному типу относятся лидеры в любой области деятельности. Такие люди жаждут влияния, известности, славы и личной власти как таковой.

VI. Религиозная - это личность, заинтересованная в понимании мира, вселенской мудрости, познания человеческого предназначения. Такие люди могут самовыражаться различными путями, но рассматривают жизнь как единство мироздания и поиск высшего смысла.

Исследователи высказали предположение, что измерение ценностей отражает основные проблемы, с которыми сталкивается та или иная социальная группа.

\section{Ценностные ориентации и мотивация социальной группы «Студенты»}

Успеваемость студентов зависит от различных факторов, к которым относится не только уровень интеллектуального развития, врожденные и приобретенные в 
момент становления способности и умение использовать полученные знания, морально-психологический климат в семье и учебном заведении, но также зависит и от ценностных ориентаций, мотивов, интересов, личностных качеств, самосознания и самопредставления и др.

Для того чтобы оптимизировать работу студентов, раскрыть потенциальные возможности, необходимо создать условия для их активности в определенной сфере деятельности. Ценности - то, что действительно важно для студента и выступает движущей силой, т.е. мотивом для достижения его целей.

Очень важной потребностью студентов является общение. Оно стимулирует развитие дружеских отношений в коллективе, что способствует взаимовыручке, обмену знаниями и опытом, а также поддержанию нормальной самооценки учащихся.

Потребность в достижениях также актуальна для студентов. Множество исследований показывают важность духовных потребностей обучающихся и их связь с эффективностью деятельности в процессе обучения. Абсолютно очевидно, что студент, который не познал самого себя, не может поставить четкие цели и двигаться к их достижению, что оказывает существенное влияние на уровень успеваемости.

Как уже было сказано выше, обучение студентов зависит от их самосознания, от понимания особенностей своей личности и характера, например от стрессоустойчивости, уровня ответственности и тревожности, а также от степени адекватности самооценки.

Если у студента очень низкий или слишком высокий уровень тревожности, низкий уровень ответственности и стрессоустойчивости, то это непременно будет влиять на уровень мотивации, вероятнее всего она будет недостаточной, такие студенты, как правило, попадают в число отстающих.

Характер учебной мотивации также является важнейшим фактором, влияющим на успешность обучения в вузе. Можно разделить мотивацию на недостаточную и положительную, где недостаточная - недооценка смысла и/или значения ожидаемого результата своей деятельности. Положительная мотивация это - стимулы (побудительные причины), которые провоцируют нас на достижение выгоды с позитивным подтекстом. К последней относятся познавательные, профессиональные, а также моральные мотивы. Таким образом, можно предположить, что успешность обучения тесно связана с мотивацией. Положительная мотивация поспособствует успешному обучению, в то время как недостаточная - серьезно усложнит путь к успеху. А при анализе ценностей и возникающих в соответствии с ними мотивов определяется направленность индивида на получение знаний и выборе профессии в интересующей области.

Студенты, выбирающие ценность «знание» как приоритетную, характеризуются высокой эффективностью учебной деятельности, они целеустремленные и обладают силой воли. В то время как студенты, имеющие ценность «получение профессии», довольно избирательны в отношении дисциплин. Они выбирают для себя «полезные» предметы, которые пригодятся им на будущей работе и концентрируются на них, что часто сказывается на уровне успеваемости. Как утверждает Булано- 
ва-Топоркова М.В. студенты с ценностью «получение диплома» даже избирательно не подходят к изучению дисциплин, предоставляемым в ВУЗе, зачастую не заинтересованы в получении знаний, поэтому нерегулярно посещают занятия, используют шпаргалки во время экзаменационных сессий, задерживают сдачи учебных заданий и т.п. (Буланова-Топоркова, 2002: 132).

Как отмечает автор одного из наиболее объемных исследований психологических особенностей студентов - Иванников В.А., основным фактором, влияющим на успешность учебной деятельности, являются не проявленные психические процессы личности, а их формирование, в котором ведущую роль играют волевые качества (Иванников, 1991: 20).

Подчеркнем, что в случае недостаточной мотивации студентов, им следует проявлять свои волевые качества ради достижения цели, которая может обуславливаться социальной необходимостью. Здесь большое значение имеет механизм волевого действия, представляющий собой восполнение дефицита студенческой мотивации посредством умышленного усиления мотива данного действия и ослабления мотивов конкурирующих действий. Подобный механизм может использовать сам студент, заставляя себя делать то, что не всегда нравится, или педагоги, влияя на внутреннее убеждение студента в пользу обучения, представления мотивов, которые могут откликнуться в сознании студента и сдвигая мотивы на цель. При этом важно создать условия для возникновения познавательной потребности и познавательных интересов, сделать процесс обучения интересным, вовлекая студента в дискуссии, помогая сформировывать мотивы и установки для благоприятного преодоления любых препятствий по достижению поставленной цели.

Мы предполагаем, что ценностные ориентации у современных студентов гуманитарных ВУЗов связаны с их уровнем мотивации достижения успеха. Чтобы подтвердить или опровергнуть наше предположение, мы планируем провести исследование с использованием следующих методик:

1. Методика «Ценностные ориентации» М. Рокича, которая позволяет определить содержательную сторону направленности личности и составляет основу ее отношений к окружающему миру, к другим людям, к себе самой, основу мировоззрения и ядро мотивации жизненной активности, основу жизненной концепции и «философии жизни». М. Рокич различает два класса ценностей. Терминальные убеждения в том, что какая-то конечная цель индивидуального существования настолько важна, чтобы стремиться к ее достижению. Инструментальные - убеждения в том, что определенное поведение или качества и черты личности являются преимущественными в определенной ситуации. (Рокич, 2009: 26-28)

2. «Опросник для оценки мотивации достижения Элерса» предназначен для определения уровня мотивации к достижению цели к успеху. Результаты исследования позволят найти взаимосвязь ценностей студентов с их мотивацией, спрогнозировать последующее развитие личности и профессиональной деятельности будущих специалистов, обозначить пути их совершенствования. 
Мы предполагаем, что на первом месте у студентов гуманитарных ВУЗов будут выявлены такие терминальные ценности как здоровье, интересная работа, счастливая семейная жизнь, а на последнем - жизненная мудрость и деятельная жизнь.

Также мы предполагаем, что среди инструментальных ценностей на первом месте будут: образованность, ответственность, рационализм и аккуратность. В целом мы предполагаем, что большинство опрошенных будут иметь среднюю мотивацию.

\section{СПИСОК ЛИТЕРАТУРЫ}

Буланова-Топоркова, М.В. (2002) Педагогика и психология высшей школы: учебное пособие. Ростов-на-Дону: Феникс. 544 с.

Иванников, В.А. Психологические механизмы волевой регуляции: учеб. пособие; МГУ. - 3-е изд. - СПб.: Питер, 2006, 142 с.

Методика Рокича Ценностные ориентации. (Тест Милтона Рокича. Психология счастливой жизни [Электронный ресурс] URL: https://psycabi.net/testy/320-metodikarokicha-tsennostnye-orientatsii-test-miltona-rokicha-issledovanie-tsennostnykhorientatsij-m-rokicha-oprosnik-tsennosti-po-rokichu (Дата обращения 09.10.2020).

Рокич, М. Методика «Ценностные ориентации» / М. Рокич. - Москва // Большая энциклопедия психологических тестов / авт.-сост. А.А. Карелин. - М.: Эксмо, 2009. - C. 26-28.

Олпорт, Г. Диспозициональная теория личности (2015) Психологический журнал [Электронный ресурc] URL: https:/psychojournal.ru/psychologists/146-gordon-olport-dispozicionalnaya-teoriya-lichnosti.html (Дата обращения 09.10.2020).

Шпрангер, Э. (2014) Формы жизни: гуманитарная психология и этика личности М.: Канон+. 400 с.

Милентьева Алена Сергеевна - обучающаяся 3 курса образовательной программы магистратуры по направлению подготовки 44.04.02 Психолого-педагогическое образование Московского гуманитарного университета. Научный руководитель Федотова Наталья Игоревна Адрес: 111395, Россия, г. Москва, ул. Юности, д. 5. Тел.: +7 (499) 374-74-59. Эл. адрес: pp.mosgu@mail.ru

Milentyeva Alyona Sergeevna - 3-year student of the master's degree program in the field of training 44.04.02 Psychological and pedagogical education of the Moscow University for the Humanities. Scientific supervisor Natalia Fedotova. Postal address: 5 Yunosti str., Moscow, 111395, Russian Federation . Tel: +7 (499) 374-74-59. E-mail: pp.mosgu@mail.ru

\section{Для цитирования:}

Милентьева А.С. Проблема формирования мотивации достижений студентов гуманитарных вузов // Научные труды Московского гуманитарного университета. 2020. №4. C. 64-68. DOI: https://www.doi.org/10.17805/trudy.2020.4.9 